\title{
Conference Report: 'John Henry Newman - a Theologian and Saint' (31 October 2019, Catholic Theological Faculty, Charles University, Prague)
}

\section{Z UZ A NA M A T ISOVSKÁ}

Regarding the recent canonisation of Cardinal John Henry Newman in October 2019, the Department of Systematic Theology and Philosophy of the Catholic Theological Faculty organised a small conference exploring his person and work on the 31st October 2019. Six speakers representing four Czech and Slovak faculties presented their 20-minute papers, each followed by a short discussion manifesting multiple aspects of this significant theologian and saint.

The meeting was opened by the keynote lecture given by the Slovak systematic theologian, Benedictine and Ph.D. graduate of the Catholic University of America Ján Dolný, OSB. Reflecting on An Essay on the Development of Christian Doctrine (1895), he described how Newman's personal inquiry established the necessary context of living faith for his thoughts and theological insight. His obedience to the recognised truth, peculiar sensibility for the importance of development, and pastoral character of theology had driven him to the realisation that the main mark of the Church is life itself, and therefore the understanding of doctrine must deepen and new features of the faith must be brought up to stay authentic and fruitful in every era.

Daniel Soukup, a literary scholar and translator of various works of Newman, focused in his talk on The Idea of University (first part published in 1852, whole book in 1973). Aiming to explain Newman's vision of the relationship between theology and other sciences as well as its relevance for the current discussion on university education, Soukup analysed the basic definition of university as a place of teaching universal knowledge. He proposed that, even though there is a great difference between what Newman was actually saying and what intellectuals nowadays tend to adopt, what is remarkable is not only the content but also the form of his ideas and the fact that Newman's personality itself illustrates the meaning of universal education, which underlines his credibility and makes him an inspiring figure even today.

František Štech, completing the first part of the conference, examined Newman's idea of development in the context of Christian revelation - the reality which is fully alive and active in the present became clear in the Incarnation but has preserved the mystery, calling one to answer by taking on a journey of evolution.

The second half of the session belonged to the three theologians from the University of South Bohemia. Tomáš Machula, the rector of USB, evaluated 
the Anglican concept of via media in dialogue with Newman's religious journey, approaching it more as a formal principle in contrast with Aristotle's concept of virtue. Jaroslav Vokoun, concerned with ecumenical dialogue and the dynamics of traditions, focused on the content of the via media concept; he claimed that it can always serve as an instrument for discerning various types of churches as well as assorted positions within communities. The final lecture of the afternoon was given by Július Pavelčík, who used an analogy between the theologian John Henry Newman and the philosopher Maurice Blondel to demonstrate their mutual emphasis on the active aspect of tradition, an interest in the movement from the implicit to the explicit, and an effort to reach a balanced view of the relationship between intellect, faith, history, and doctrine.

The life and work of John Henry Newman was formed by 'a hidden experience of fight for a wide heart and open ears for the calling of God'. ${ }^{1}$ His personal struggles bore fruit for the whole Church as it is with the life of every saint, and his honest dialogue with particular historical circumstances contributed to the general renewal of theology. Reflections presented during the conference served as the examples of enriching communication between this man of the 19 th century and current affairs.

doi: 10.14712/23363398.2020.14

1 Roman A. Siebenrock, 'John Henry Newman (1801-1890). Být křestanem v dnešním světě - model,' Teologické texty 22, no. 1 (2011). 